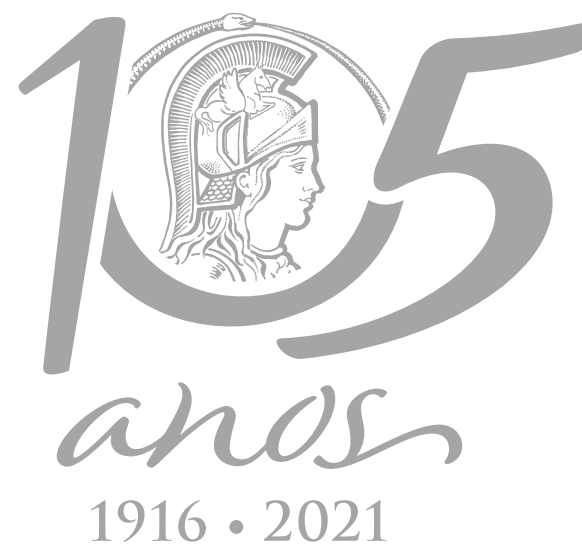

\title{
PALEONTOLOGY
}

\section{Primate diversity in the early Miocene Pinturas Formation, southern Patagonia, Argentina}

\author{
NELSON MARTÍN NOVO, MARCELO FABIÁN TEJEDOR, LAUREANO RAÚL \\ GONZÁLEZ-RUIZ, JOHN G. FLEAGLE, DIEGO BRANDONI \& MARCELO KRAUSE
}

\begin{abstract}
We report ten new dental specimens of primates from the early Miocene Pinturas Formation, Patagonia, Argentina. The new material includes: a left lower canine and a left upper canine whose affinities remain to be determined; a mandibular fragment preserving part of the symphysis; and right p3-4, practically indistinguishable from Soriacebus adrianae; and a lower molar, probably $\mathrm{m} 2$, attributable to S. ameghinorum. A lower molar, probably m3, a P4, and an upper molar resemble Carlocebus carmenensis. Three additional specimens, too damaged for an accurate taxonomic assignment, are tentatively assigned to $\mathrm{S}$. ameghinorum. The specimens here described can be assigned to taxa already known from the Pinturas Formation (S. ameghinorum, S. adrianae, and C. carmenensis) and provide new morphological information.
\end{abstract}

Key words: Platyrrhine primates, Soriacebus, Carlocebus, early Miocene, Patagonia.

\section{INTRODUCTION}

Fossil platyrrhines have been known since the first half of the XIXth century with the reports by Lund (1840) of the Pleistocene fauna of eastern Brazilian caves. After long intervals when no new fossils were found, a remarkable amount of material has been collected regarding the origin, evolutionary history and paleobiogeography of the group, especially since the 1980s. Although the number of specimens recorded is proportionally small relative to other fossil mammals, platyrrhines had a notable diversity in the past. About 35 extinct platyrrhine genera have been reported from the mid Cenozoic of Central and South America and the Caribbean islands. Most are part of the modern radiation, but the oldest South American primates discovered so far are part of a complex evolutionary scenario, such as the discovery of a possible stem platyrrhine or pre-platyrrhine (Bond et al. 2015), and a parapithecid stem anthropoid (Seiffert et al. 2020), both from the late Paleogene of the Amazon region in Peru; or the controversial the controversial genera from western Bolivia (late Oligocene, Hoffstetter 1969, Rosenberger et al. 1991a, Takai et al. 2000, Kay et al. 2002) and Chile (early Miocene; Flynn et al. 1995). Then, the more modern forms from the Peruvian Amazonia (late Oligocene; Marivaux et al. 2016a, early Miocene; Marivaux et al. 2012, Kay et al. 2019, late Miocene; Marivaux et al. 2016b, 2020), central Colombia (middle Miocene; Stirton 1951, Hershkovitz 1970, Luchterhand et al. 1986, Setoguchi \& Rosenberger 1985, Kay et al. 1987, 1997, Rosenberger et al. 1991b, Takai 1994, Takai et al. 2001, 2009), Brazil (late Miocene and Pleistocene; Lund, 1840, Hartwig \& Cartelle 1996, Cartelle \& Hartwig 1996, Kay \& Cozzuol 2006, Tejedor et al. 2008, Rosenberger et al. 2015, Halenar \& Rosenberger 2013), Panama (early Miocene; Bloch et al. 2016), and the Greater Antilles (early Miocene and late Cenozoic; Rivero \& Arredondo 1991, MacPhee et al. 2003, Williams 
\& Koopman 1952, Rosenberger 1977, MacPhee \& Horovitz 2004, Kay \& Cozzuol 2006, Kay et al. 2011, Rosenberger et al. 2011, Cooke et al. 2011).

From Argentine Patagonia (early and middle Miocene), eight genera and eleven species of fossil platyrrhines have been recorded from different formations. The oldest Patagonian primates were found in early Miocene sediments from four localities of the Sarmiento Formation (Fm.), Chubut Province. Three genera have been recovered: Tremacebus from Sacanana (Rusconi 1933, Hershkovitz 1974), Dolichocebus from Gaiman (Kraglievich 1951, Kay et al. 2008) and Mazzonicebus from the Gran Barranca (Kay 2010) and La Estrella (Novo et al. 2017). The youngest genus, Proteropithecia, was found in middle Miocene deposits of the Collón Curá Fm., Neuquén Province (Kay et al. 1998). In addition, primates have been found in the Santa Cruz Fm. (early Miocene), southeastern coastal area of Santa Cruz Province, where the number of existing genera is still controversial. At the moment, Killikaike and two species of Homunculus have been described (Ameghino 1891, Tejedor et al. 2006, Tejedor \& Rosenberger 2008, Perry et al. 2010, 2014, Kay et al. 2012, Novo et al. 2018, Kay \& Perry 2019). Finally, the most diverse fossil record of primates comes from the Pinturas Fm. (early Miocene), also in Santa Cruz Province. The Pinturas Fm. contains the second largest collection of fossil platyrrhines specimens, after the taxonomically diverse assemblage of La Venta, Colombia (see Tejedor \& Novo 2018). To date, at least two genera and four primate species have been recognized in the Pinturas Fm.: Soriacebus ameghinorum Fleagle, Powers, Conroy \& Watters, 1987, Soriacebus adrianae Fleagle 1990, Carlocebus carmenensis Fleagle 1990, and Carlocebus intermedius Fleagle 1990, with subsequent reports of isolated specimens (Fleagle \& Tejedor 2002, Tejedor 2005a, b, Novo
\& Fleagle 2015), and a third genus remains unpublished (see Tejedor et al. 2012).

It should be noted that the taxonomic assignments at a suprageneric level that we provide below strongly differ from Kay (2015, and references therein), who suggested an alternative hypothesis considering the Patagonian primates as a stem family group, excepting Proteropithecia (Pitheciidae).

In this contribution, we report ten new dental specimens of primates from the Pinturas Fm. that provide additional morphological information on several taxa.

\section{GEOLOGICAL BACKGROUND}

The Pinturas Fm. is a pyroclastic and epliclastic succession, around 70-80 m thick, cropping out in the upper valley of the Pinturas river and its tributaries, in the northern Santa Cruz Province, Patagonia, Argentina (Bown \& Larriestra 1990). Currently, the Pinturas Fm. is divided into four informal 'sequences', separated by unconformities (Krause et al. 2016), a scheme that modifies the former tripartite division scheme of Bown \& Larriestra (1990). The ${ }^{40} \mathrm{Ar} /{ }^{39} \mathrm{Ar}$ ages of $\sim 17.99 \mathrm{Ma}$ near the base of the Pinturas Fm. at Estancia el Carmen, and $16.8 \mathrm{Ma}$ of the overlaying Santa Cruz Fm. at Portezuelo Sumich Norte (see Perkins et al. 2012, Fleagle et al. 2012) suggest that the Pinturas Fm. is Burdigalian in age (20.44-15.97 Ma, Cohen et al. 2013). Eight localities of this unit have been described by Bown \& Larriestra (1990) as providing confident sedimentary sections and fossil primates: Arroyo Feo (AF), Estancia El Carmen (EEC), Estancia Ana María (EAM) (hereafter 'Loma de las Ranas (LR)'), Loma de la Lluvia (LL), Cauce Seca (CS), Cerro de los Monos (CM), Portezuelo Sumich Sur (PSS), and Portezuelo Sumich Norte (PSN) (Fig.1). The new fossils reported here come from PSN (S 46 $57^{\prime}$ 

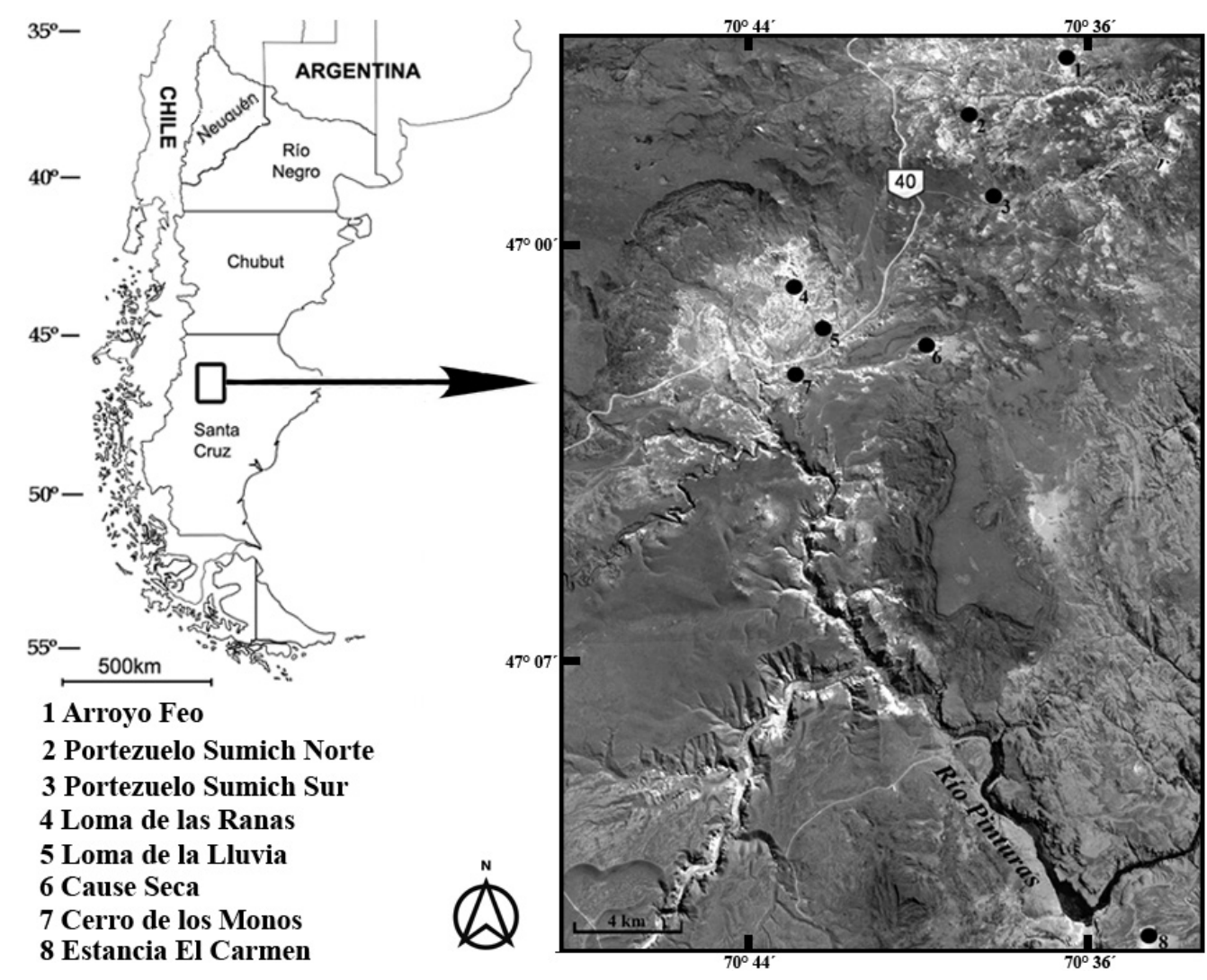

Figure 1. Map of Patagonia showing the location and detail of the Pinturas River area and the localities mentioned in the text.

33.09", W $70^{\circ} 9340^{\prime} 2^{\prime \prime}$ ), LR (S 470 01' 30,8", W $70^{\circ} 43^{\prime}$ 50,3"), and PSS (S 46 94 59' 7.3", W 70 38' 21.7"). Platyrrhines from PSN and LR derive from the second sequence from the base of the formation. This sequence coincides with the "sandy yellow, green or pink bentonitic mudstone" of Bown \& Larriestra (1990), and is composed of fine- to medium-grained sandstone, yellowish grey in color. The lower boundary is represented by an erosional, irregular surface (i.e., unconformity), up to $15 \mathrm{~m}$ in relief, which truncates the first sequence, characterized by stacked, pinkish paleosols ('very mature paleosols' of Bown and Larriestra 1990). At PSN, this surface is clearly visible and was interpreted as a paleovalley by Bown \& Larriestra 1990: fig. 9A). At LR, the base of the section does not crop out. However, observations in surrounding outcrops in the EAM area show the fossiliferous level in a similar stratigraphic position as for PSN; that is, between the very mature paleosols interval (first sequence) and the eolian dunes interval (third sequence, formerly second sequence of Bown \& Larriestra 1990). PSS consists of an isolated outcrop distant from other localities, and was not directly correlated to them. Bown and Larriestra (1990: 113), based on the presence of sandy gray volcanic mudrocks in this place, and its strong similarity regarding the interdune beds from the third sequence (former 'middle sequence' of Bown and Larriestra 1990), correlated this locality to it, giving a younger relative age for fossils from PSS relative to those from PSN. Our recent observations in the field accord with the higher stratigraphic position of PSS with respect to both PSN and LR. However, we tentative correlate this locality to the lowermost fourth sequence, as the light gray rocks can be followed to the north up to the higher part of the outcrop at PSN. 


\section{MATERIALS AND METHODS}

\section{Institutional abbreviations}

MACN Pv SC, Museo Argentino de Ciencias Naturales "Bernardino Rivadavia”, Buenos Aires, Argentina; Colección de Paleovertebrados-Santa Cruz; MPM-PV, Museo Regional Provincial Padre Manuel Jesús Molina, Río Gallegos, Argentina.

\section{Anatomical abbreviations}

The dentition of the Patagonian fossil primates is discussed using the following abbreviations: M1-3, upper molars; m1-3, lower molars, p/P lower and upper premolars, c/C lower and upper canines, i/I lower and upper incisors. BL: buccolingual; MD: mesiodistal.

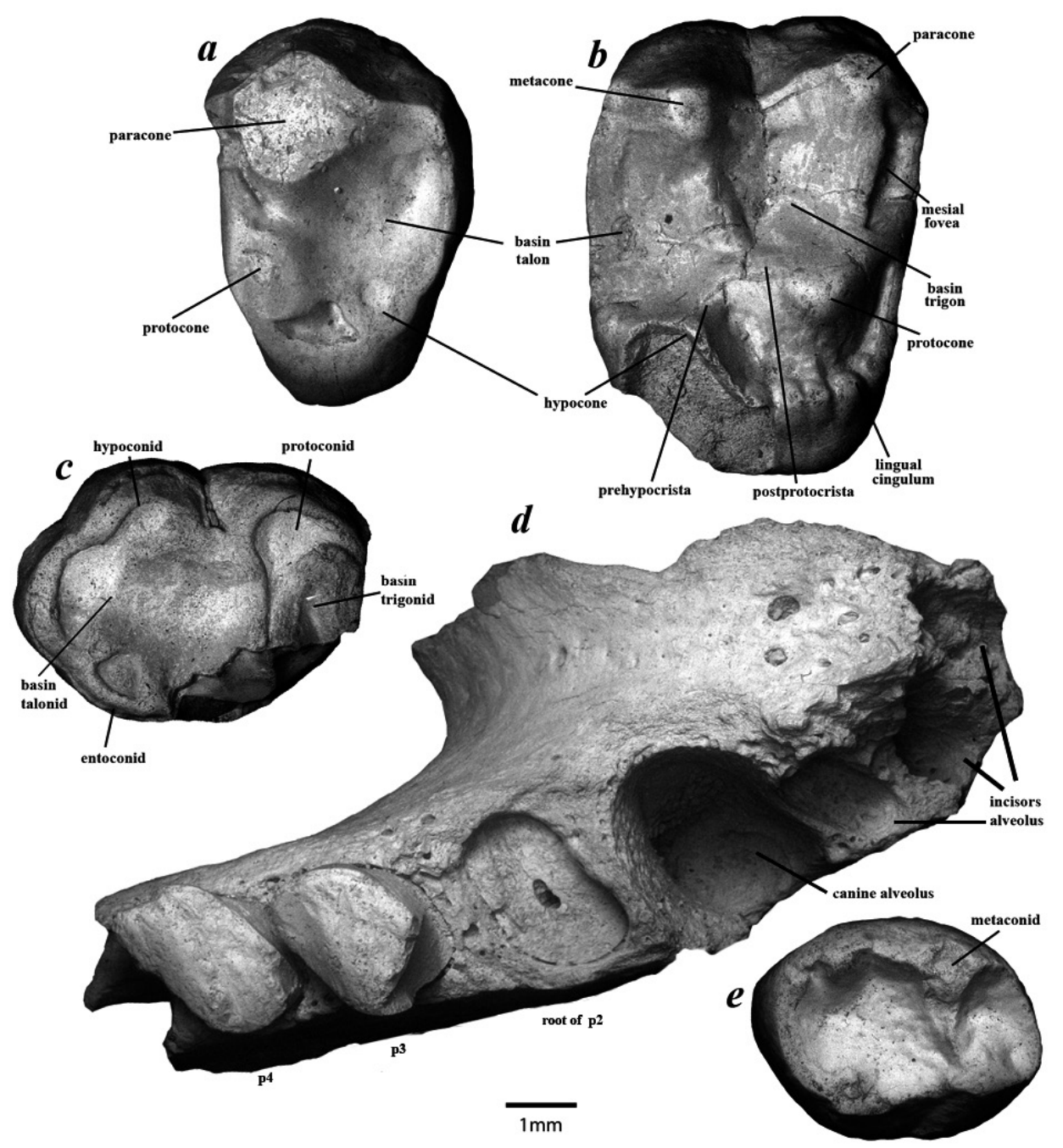

\section{Systematic paleontology}

Class Mammalia Linnaeus, 1758

Order Primates Linnaeus, 1758

Parvorder Platyrrhini Geoffroy Saint-Hilaire, 1812

Family Pitheciidae Gray, 1849 (Mivart, 1865)

Genus Soriacebus Fleagle, Powers, Conroy \& Watters, 1987

Type species: Soriacebus ameghinorum Fleagle, Powers, Conroy \& Watters, 1987

\section{Soriacebus ameghinorum}

Referred material: MPM PV 17413 (Fig. 2e), right lower molar, probably m2.
Figure 2. Occlusal view of new specimens from the Pinturas Formation. a: MPM PV 21646 left P4, b: MPM PV 17417 left M1 or M2, c: MPM PV 17416 left m3, d: MPM PV 17419 symphysis mandibular, e: MPM PV 17413 right m2. Scale bar $1 \mathrm{~mm}$. 
Geographic and stratigraphic provenance: Portezuelo Sumich Norte, Santa Cruz Province. Second sequence of the Pinturas Fm.

Description: The roots are broken but it possibly had a divided mesial root, and a single, distal one. The trigonid is slightly higher than the talonid, mesially closed, and somewhat expanded mesially beyond the protoconid due to the presence of a straight preprotocristid, not as long as seen in the type of S. ameghinorum, giving the latter a more expanded trigonid in proportion to the talonid. The protoconid is moderately developed, connecting to the metaconid obliquely through the lateral protocristid forming the distal wall of the trigonid. The talonid is expanded distally behind the entoconid and hypoconid. The ectoflexid is slightly marked, differing from the type; the cristid obliqua is oriented forward reaching the wall of the trigonid behind the protoconid. There is a small cuspule twinned to the entoconid that may be homologous to the hypoconulid. The general outline of the molar is rounded, unlike the more elongate and quadrangular aspect of the type of S. ameghinorum, and more similar to MPM PV 36, described as Soriacebus cf. ameghinorum by Tejedor (2005a). However, MPM PV 17413 has an even more rounded aspect, and the lingual side is more inflated than both of the aforementioned specimens. Based on its morphology and size, this $\mathrm{m} 1$ could be assigned to Soriacebus with certainty, although there are some important morphological differences, as was mentioned for MPM PV 36 (Tejedor 2005a), thus questioning the specific status.

\section{cf. Soriacebus ameghinorum}

Referred material: MPM PV 17412, left lower molar; MPM PV17396, talonid of a left lower molar; MPM PV 17415, mandibular fragment with the broken and worn talonid of a lower molar preserving a complete distal root.

Geographic and stratigraphic provenance: The three specimens come from Portezuelo Sumich Norte, Santa Cruz Province. Second sequence of the Pinturas Fm.

Description: MPM PV 17412 is a heavily worn molar with almost no occlusal morphology preserved, except in the talonid basin. The anterior root is complete, but the posterior one is broken, so it is not possible to determine whether it is bifid or not. It is not possible to determine exactly the taxonomic assignment of MPM PV 17415 and MPM PV17396 due to wear. However, based on the crown outline and size, these three specimens may be comparable to the lower molars of S. ameghinorum.

Type species: Soriacebus adrianae Fleagle, 1990

\section{Soriacebus adrianae}

Referred material: MPM PV 17419 (Fig 2d), symphysis with right p3-4 broken and preserving only the base of the cusps, root of right p2, alveolus of the right canine, and partial alveoli of the incisors.

Geographic and stratigraphic provenance: Loma de las Ranas, Santa Cruz Province. Second sequence of Pinturas Fm.

Description: This specimen is indistinguishable from S. adrianae especially the holotype, MACN Pv SC59, and the symphysis MPM PV 1605, based on the general size, V-shaped morphology of the dental arcade, procumbent incisors, as indicated by the position of the alveoli, and relatively large alveolous of the canine.

Genus Carlocebus Fleagle, 1990

Type species Carlocebus carmenensis Fleagle, 1990 


\section{Carlocebus carmenensis}

Referred material: MPM PV 21646 (Fig. 2a) left P4; MPM PV 17417 (Fig. 2 b) right M1 or M2; MPM PV 17416 (Fig. 2c) left m3.

Geographic and stratigraphic provenance: MPM PV 21646 from Portezuelo Sumich Sur, MPM PV 17417 and MPM PV 17416 from Loma de las Ranas, Santa Cruz Province. From the fourth and second sequences, respectively.

Description: The MPM PV 21646 P4 has two fused roots, unlike the three roots present in some upper premolars of S. ameghinorum. It has a well-developed paracone worn at the tip, and a small protocone separated by a sulcus continuous with a mesial fovea. It shows a moderately developed lingual cingulum bearing a hypocone. There is a short preparacrista and a longer, distally oriented postparacrista delimiting buccally a relatively wide talon basin. In overall morphology, this $\mathrm{P} 4$ is almost indistinguishable from the $\mathrm{P} 4$ in the maxilla MACN Pv SC400 (from Estancia El Carmen), attributed to C. carmenensis (see Fleagle 1990), but differs from the P4 in MACN Pv SC100 (Cerro de los Monos), attributed to an undescribed taxon (Tejedor et al. 2012), which is more elliptical, with more bulbous cusps and the lingual cingulum is expanded distally, thus contrasting with the triangular shape in C. carmenensis.

The MPM PV 17417 upper molar has the root area completely broken, as well as the lingual part of the hypocone. The strong lingual cingulum has accessory cuspules and is expanded as a precingulum as in MACN Pv SC317, an M1 assigned to $C$. carmenensis. A very weak labial cingulum is also present. The talon basin is broad, distally expanded. The mesial fovea is present and deeper than in MACN PV SC90 and MACN PV SC254, also attributed to C. carmenensis, and it is delimited by a developed hypoparacrista descending from the paracone and reaching the preprotocrista at about the middle and anterior part of the tooth. Paracone and metacone are well developed forming a V-shaped ectoflexid due to the connection of the postparacrista and premetacrista. There is a tiny metaconule at the end of the descending hypometacrista. A quadrangular shape is produced by the well-developed hypocone connected to the labially oriented postprotocrista by a short prehypocrista, unlike some molars assigned to $C$. carmenensis, where the prehypocrista is absent (i.e., MACN Pv SC90 and MACN Pv SC317). Nevertheless, given its similar morphology with previously assigned specimens, such as MACN Pv SC270, MACN Pv SC98, MACN Pv SC230, MPM PV 17403, among others, this new upper molar is assignable to $C$. carmenensis.

The MPM PV $17416 \mathrm{~m} 3$ is heavily worn and its mesolingual region is broken. It has two fused roots. The trigonid is shorter and the talonid has a relatively wide basin, although mesiodistally short. The talonid is expanded distally forming a lobe. The hypoconid appears broad at the base, larger than the entoconid. There is a small sulcus distal to the entoconid separating a tiny and worn cusp, as well as the distal lobe; this cusp is more evident in MACN Pv SC248, an m3 attributed to $C$. carmenensis (see Fleagle 1990), which this molar resembles in general morphology.

\section{Genus indeterminate}

Referred material: MPM PV 17414 (Fig. 3c, d) left lower canine; MPM PV 17418 (Fig. 3a, b) left upper canine.

Geographic and stratigraphic provenance: MPM PV 17414 is from PSN, whereas MPM PV 17418 is from Loma de las Ranas, Santa Cruz province, second sequence of the Pinturas Fm.

Descriptions: The MPM PV 17414 lower canine has a well preserved crown, except its 


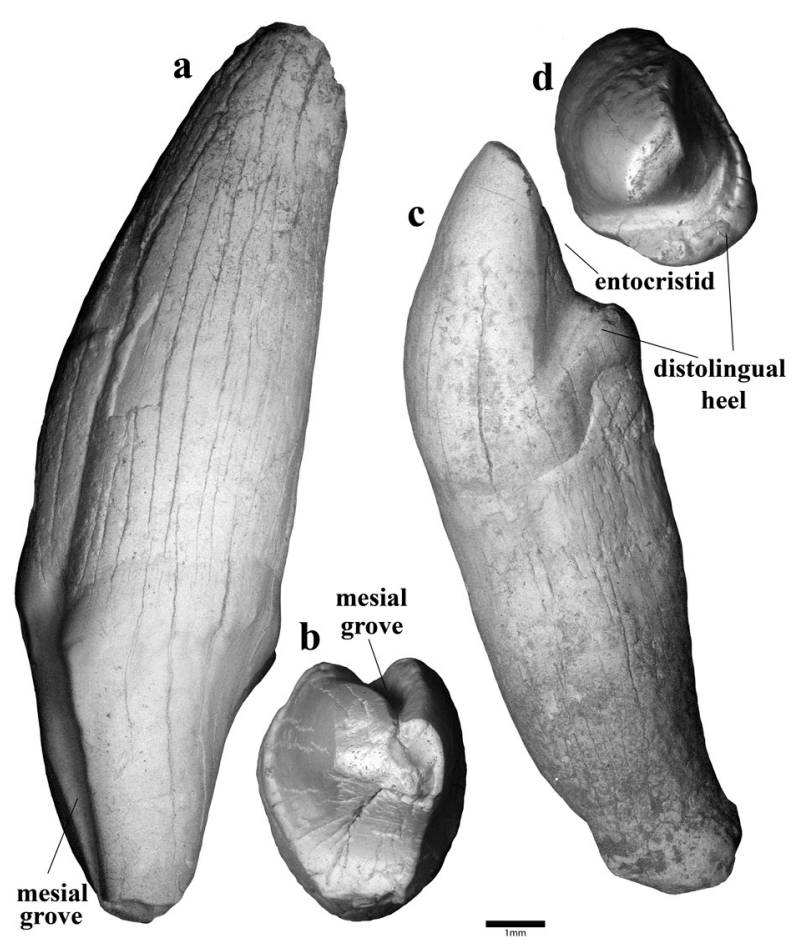

Figure 3. New specimen from Pinturas Formation: a MPM PV 17418 lingual view of the upper canine, b: occlusal view of the MPM PV 17418, c: MPM PV 17414 labial view of the lower canine, $d$ : occlusal view of the MPM PV 17414. Scale bar 1mm.

tip which is worn and somewhat broken. It has moderate distolingual heel and rounded entocristid. It has an elliptical cross-section, but the shaft of the crown between the cingulum and the apex is rather triangular given by the large open lingual surface and the flat distal surface associated with the entocristid. This is a classical lower canine pitheciine morphology in a somewhat more primitive state. This new canine is approximately the same size as MPM PV 17395 and MPM PV 17397, two primate canines indet reported by Novo \& Fleagle (2015), although the latter two are more bucolingually compressed with a reduced lingual cingulum. However, MPM PV 17414 resembles the canine in the type of S. ameghinorum in its general outline, well developed lingual cingulum and lingual heel, but differs in its smaller size.
The MPM PV 17418 upper canine has a large and robust crown with a deep mesial grove. It is even larger and more robust compared to the upper canine of $S$. ameghinorum in the maxilla MACN Pv SC4, especially in buccolingual dimensions. It has moderate talon wear and heavy wear in the lingual region where it occludes with p2. Among all canines reported from the Pinturas Fm., MPM PV 17418 appears more similar to MACN Pv SC328, the largest canine with a distinct morphology which is described by Tejedor (2002).

\section{DISCUSSION}

The specimens described above have been tentatively assigned to previously known taxa from the Pinturas Fm. including Soriacebus ameghinorum, S. adrianae, and Carlocebus carmenensis, and they provide additional morphological information on the variation of those taxa. Consequently, a thorough revision is needed for the whole primate collection of the Pinturas Fm. in order to better evaluate the taxonomic significance of the morphological variation among them, and to assess the possibility of additional new taxa. (Fleagle 1990, Tejedor 2005a, Tejedor et al. 2012).

The correlations of taxa and sequences at Pinturas are as follows, from the base to the top of the section (Table I): 1) First sequence (Estancia el Carmen), Carlocebus carmenensis; 2) second sequence (Arroyo Feo, Portezuelo Sumich Norte, Loma de las Ranas, Loma de la Lluvia, Cauce Seca), Carlocebus carmenensis, Soriacebus adrianae, Soriacebus ameghinorum, and Carlocebus intermedius; 3 ) third sequence (Cerro de los Monos), a third genus remains unpublished (see Tejedor et al. 2012). 4) fourth sequence (Portezuelo Sumich Sur), Soriacebus adrianae, Carloebus carmenensis. 
Table I. The Pinturas Formation specimens previously reported and mentioned in the text. Measurements (in mm).

\begin{tabular}{|c|c|c|c|c|c|c|c|}
\hline Colection $\mathbf{N}^{\circ}$ & Species & Description & Location & Sequence & BL & MD & References \\
\hline MPM-PV 17412 & $\begin{array}{c}\text { cf. S. } \\
\text { ameghinorum }\end{array}$ & left $\mathrm{m} 1$ or 2 & $\begin{array}{l}\text { Portezuelo } \\
\text { Sumich Norte } \\
\text { Fm. Pinturas } \\
\text { Santa Cruz }\end{array}$ & second & 3.58 & 4.09 & new \\
\hline MPM-PV 17413 & $\begin{array}{c}\text { S. } \\
\text { ameghinorum }\end{array}$ & $\begin{array}{c}\text { right m, probably } \\
\text { m2 }\end{array}$ & $\begin{array}{l}\text { Portezuelo } \\
\text { Sumich Norte } \\
\text { Fm. Pinturas } \\
\text { Santa Cruz }\end{array}$ & second & 3.25 & 4.07 & new \\
\hline MPM-PV 17414 & indet & left c & $\begin{array}{l}\text { Portezuelo } \\
\text { Sumich Norte } \\
\text { Fm. Pinturas } \\
\text { Santa Cruz }\end{array}$ & second & 4.45 & 3.59 & new \\
\hline MPM PV 17415 & $\begin{array}{c}\text { cf. S. } \\
\text { ameghinorum }\end{array}$ & $\begin{array}{l}\text { mand. frag. with } \\
\text { talonid of m1 or } 2\end{array}$ & $\begin{array}{l}\text { Portezuelo } \\
\text { Sumich Norte } \\
\text { Fm. Pinturas } \\
\text { Santa Cruz }\end{array}$ & second & & & new \\
\hline MPM PV 17396 & $\begin{array}{c}\text { cf. S. } \\
\text { ameghinorum }\end{array}$ & talonid of $\mathrm{m} 1$ or 2 & $\begin{array}{l}\text { Portezuelo } \\
\text { Sumich Norte } \\
\text { Fm. Pinturas } \\
\text { Santa Cruz }\end{array}$ & second & 3.19 & & new \\
\hline MPM-PV 17416 & C. carmenensis & left m3 & $\begin{array}{l}\text { Loma de las } \\
\text { Ranas Fm. } \\
\text { Pinturas, Santa } \\
\text { Cruz }\end{array}$ & second & 4.2 & 5.46 & new \\
\hline MPM-PV 17417 & C. carmenensis & $\begin{array}{l}\text { right m, probably } \\
\text { m2 }\end{array}$ & $\begin{array}{l}\text { Loma de las } \\
\text { Ranas Fm. } \\
\text { Pinturas, Santa } \\
\text { Cruz }\end{array}$ & second & 6.85 & 4.95 & new \\
\hline MPM-PV 17418 & indet. & left C & \begin{tabular}{l} 
Loma de las \\
Ranas Fm. \\
Pinturas, Santa \\
\multicolumn{2}{c}{ Cruz }
\end{tabular} & second & 3.87 & 5.1 & new \\
\hline MPM-PV 17419 & S. adrianae & $\begin{array}{c}\text { symphysis with } \\
\text { p3-4 }\end{array}$ & \begin{tabular}{l} 
Loma de las \\
Ranas Fm. \\
Pinturas, Santa \\
\multicolumn{2}{c}{ Cruz }
\end{tabular} & second & & & new \\
\hline $\begin{array}{c}\text { MPM- } \\
\text { PV-21646 }\end{array}$ & $\begin{array}{c}\text { cf. C. } \\
\text { carmenensis }\end{array}$ & left P4 & $\begin{array}{l}\text { Portezuelo } \\
\text { Sumich Sur } \\
\text { Fm Pinturas, } \\
\text { Santa Cruz }\end{array}$ & fourth & 5.48 & 3.78 & new \\
\hline $\begin{array}{c}\text { MACN Pv SC2 } \\
\text { (h) }\end{array}$ & $\begin{array}{c}\text { S. } \\
\text { ameghinorum }\end{array}$ & $\begin{array}{l}\text { mand. frag. with } \\
\text { right i1, m3, and } \\
\text { left c root }\end{array}$ & $\begin{array}{l}\text { Portezuelo } \\
\text { Sumich Norte } \\
\text { Fm. Pinturas } \\
\text { Santa Cruz }\end{array}$ & second & & & $\begin{array}{c}\text { Fleagle et al. } \\
1987\end{array}$ \\
\hline MACN Pv SC4 & $\begin{array}{c}\text { S. } \\
\text { ameghinorum }\end{array}$ & $\begin{array}{l}\text { max. frag. with } \\
\text { left C-M1 }\end{array}$ & $\begin{array}{l}\text { Portezuelo } \\
\text { Sumich Norte } \\
\text { Fm. Pinturas } \\
\text { Santa Cruz }\end{array}$ & second & & & $\begin{array}{c}\text { Fleagle et al. } \\
1987\end{array}$ \\
\hline
\end{tabular}


Table I. Continuation

\begin{tabular}{|c|c|c|c|c|c|c|c|}
\hline Colection $\mathbf{N}^{\circ}$ & Species & Description & Location & Sequence & BL & MD & References \\
\hline $\begin{array}{l}\text { MACN PV } \\
\text { SC59 (h) }\end{array}$ & S. adrianae & $\begin{array}{c}\text { mand. symphysis } \\
\text { with left partial } \\
\text { canine, left p3- } \\
4 \text {, p2 root and } \\
\text { alveolus of i and } \\
\text { m1 }\end{array}$ & $\begin{array}{l}\text { Portezuelo } \\
\text { Sumich Sur } \\
\text { Fm Pinturas, } \\
\text { Santa Cruz }\end{array}$ & fourth & & & Fleagle 1990 \\
\hline $\begin{array}{l}\text { MACN PV } \\
\text { SC266(h) }\end{array}$ & C. carmenensis & $\begin{array}{l}\text { mand. frag. with } \\
\text { right p4-m2 and } \\
\text { alveolus of p2-3 } \\
\text { and m3 }\end{array}$ & $\begin{array}{l}\text { Estancia } \\
\text { El Carmen } \\
\text { Fm. Pinturas } \\
\text { Santa Cruz }\end{array}$ & first & & & $\begin{array}{c}\text { Fleagle et al. } \\
1987\end{array}$ \\
\hline $\begin{array}{l}\text { MACN PV } \\
\text { SC400 }\end{array}$ & C. carmenensis & $\begin{array}{l}\text { max. frag. with } \\
\text { left P4-M3 }\end{array}$ & $\begin{array}{l}\text { Loma de } \\
\text { la Lluvia } \\
\text { Fm. Pinturas } \\
\text { Santa Cruz }\end{array}$ & second & & & Fleagle 1990 \\
\hline $\begin{array}{l}\text { MACN PV } \\
\text { SC317 }\end{array}$ & C. carmenensis & right M2 & $\begin{array}{c}\text { Loma de las } \\
\text { Ranas, Fm. } \\
\text { Pinturas, Santa } \\
\text { Cruz }\end{array}$ & second & & & Fleagle 1990 \\
\hline $\begin{array}{l}\text { MACN PV } \\
\text { SC90 }\end{array}$ & C. carmenensis & left M2 & $\begin{array}{l}\text { Portezuelo } \\
\text { Sumich Sur } \\
\text { Fm Pinturas, } \\
\text { Santa Cruz }\end{array}$ & fourth & & & Fleagle 1990 \\
\hline $\begin{array}{l}\text { MACN PV } \\
\text { SC254 }\end{array}$ & C. carmenensis & right M2 & $\begin{array}{l}\text { Portezuelo } \\
\text { Sumich Sur } \\
\text { Fm Pinturas, } \\
\text { Santa Cruz }\end{array}$ & fourth & & & Fleagle 1990 \\
\hline $\begin{array}{c}\text { MACN Pv SC3 } \\
\text { (h) }\end{array}$ & C. intermedius & $\begin{array}{l}\text { mand. frag. with } \\
\text { left broken c-m2 } \\
\text { and m3 root }\end{array}$ & $\begin{array}{l}\text { Portezuelo } \\
\text { Sumich Norte } \\
\text { Fm. Pinturas, } \\
\text { Santa Cruz }\end{array}$ & second & & & Fleagle 1990 \\
\hline $\begin{array}{l}\text { MACN PV } \\
\text { SC100* }\end{array}$ & $\begin{array}{l}\text { new genus } \\
\text { unpluplished }\end{array}$ & $\begin{array}{c}\text { max. frag. with } \\
\text { left I2, P4, M1, M3, } \\
\text { P2-3 roots and } \\
\text { M2, C alveolus, } \\
\text { and right P2-M3 } \\
\text { roots }\end{array}$ & $\begin{array}{c}\text { Cerro de los } \\
\text { Monos Fm. } \\
\text { Pinturas, Santa } \\
\text { Cruz }\end{array}$ & third & & & $\begin{array}{l}\text { Fleagle } 1990 \\
\text { (see Tejedor } \\
\text { et al. 2012). }\end{array}$ \\
\hline
\end{tabular}

Abbreviations: h: holotype; mand: mandibular; frag: fragment; max: maxillary; Fm: Formation; * specimen currently attributed to C. Carmenensis.

In the succession of the Pinturas primate fauna, the genus Soriacebus is represented in successive levels in the section, with $S$. ameghinorum, known from about 25 dental specimens, older and larger than S. adrianae, which is known from about 16 dental specimens. The specimen MPM PV10413 reported here is another example of the variation seen among isolated molars of S. ameghinorum with respect to the holotype MACN PV SC2, as the latter is more rectangular and elongate. With the current evidence, we cannot confirm if the differences may be due to an intraspecific variation or a distinct species, as suggested by Tejedor (2005a); however, another non-typical Soriacebus specimen such as MPM PV 10413 cautions us about the high morphological diversity in the Pinturas primates that deserves more scrutiny. 
The specimen MPM PV 17419 contributes to the knowledge of the poorly known species $S$. adrianae, which is only recorded from localities of the second sequence, such as PSS, LR, and LL. In addition, the lower canine MPM PV 17414 exhibits strong resemblances to the holotype of S. ameghinorum, which supports the pitheciine affinities of the latter, whereas the upper canine MPM PV 17718 is more robust than expected for Soriacebus, similar to the possible alouattine morph described by Tejedor (2002) with respect to another Pinturas upper canine.

Carlocebus carmenensis is widely distributed in the section, with almost 40 specimens reported in all the mentioned localities of the Pinturas Fm., even in Cerro de los Monos. However, several specimens coming only from $\mathrm{CM}$, at the base of the third sequence, are being reallocated to a new genus (see Tejedor et al. 2012; M.F. Tejedor et al., unpublished data); this is the only locality that corresponds to the third sequence, and therefore one of the youngest for primates. Finally, with only two dental specimens, the poorly known $C$. intermedius is only recorded in Portezuelo Sumich Norte.

The fossils comprising the whole "Pinturan fauna" come from the first three sequences, including rodents (Kramarz \& Bellosi 2005), native ungulates (Kramarz \& Bond 2005), xenarthrans (González et al. 2006, Brandoni et al. 2016, 2019), marsupials (Bown \& Fleagle 1993, Goin et al. 2010, Chornogubsky \& Kramarz 2012) and a relatively high diversity of primates (Fleagle et al. 1987, Fleagle 1990, Tejedor 2002, 2005a, b, Novo \& Fleagle 2015). As mentioned elsewhere (see Brandoni et al. 2016, and literature therein), fossils collected in the fourth sequence correspond to the more typical mammals of the "Santacrucian fauna" from the Santa Cruz Fm., on the Atlantic coast of Santa Cruz Province.

\section{Acknowledgments}

We thank the staff of Museo Regional Provincial Padre Manuel Jesús Molina (MPM-PV) and Museo Argentino de Ciencias Naturales (MACN). To ALUAR (Aluminios Argentinos, Puerto Madryn) and J. Groizard and MD. Luquet for providing access to the Scanning Electron Microscope to produce the pictures of both figures. To Museo Nacional de Río de Janeiro, Brasil, and the curator of the Mammalogy Collection J. Alves and S. Maia Vaz for allowing access to author NMN to study the material of living platyrrhines. This work was funded by CONICET, FonCyT, Argentina (PICT 2015 № 2036 to NMN and PICT 2011 № 2520, and PICT 2014 № 1818 to MFT), and a National Geographic Society research grant to JGF.

\section{REFERENCES}

BLOCH JI ET AL. 2016. First North American fossil monkey and early Miocene tropical biotic interchange. Nature 533: 243-246.

BOND M, TEJEDOR MF, CAMPBELL KE, CHORNOGUBSKY L, NOVO NM \& GOIN F. 2015. Eocene primates of South America and the African origins of New World monkeys. Nature 520: 538-541.

BOWN TM \& LARRIESTRA CN. 1990. Sedimentary paleoenvironments of fossil platyrrhine localities, Miocene Pinturas Formation, Santa Cruz Province, Argentina. J Hum Evol 19: 87-119.

BOWN TM \& FLEAGLE JG 1993. Systematics, biostratigraphy, and dental evolution of the Palaeothentidae, later Oligocene to early- middle Miocene (DeseadanSantacrucian) caenolestoid marsupials of South America. J Paleontol 67: 1-76.

BOWN TM, LARRIESTRA CN \& POWERS DW. 1988. Análisis paleoambiental de la Fm. Pinturas (Mioceno Inferior), Provincia de Santa Cruz. Segunda Reunión Argentina de Sedimentología, Actas 1: 31-35.

BRANDONI D, GONZÁLEZ RUIZ L, TEJEDOR MF, MARTIN G \& FLEAGLE JG. 2016. Megatherioidea (Mammalia, Xenarthra, Tardigrada) from the Pinturas Formation (early miocene), Santa Cruz Province (Argentina) and their chronological implications. Paläontol Z 90: 619-628.

BRANDONI D, NOVO NM, TARQUINI J \& TEJEDOR MF. 2019. First record of Nematherium (Xenarthra, Mylodontidae) from the Pinturas Formation (Burdigalian, early Miocene), Santa Cruz Province, Argentina. J South Am Earth Sci 96: 0895-9811. 
CARTELLE C \& HARTWIG WC. 1996. A new extinct primate among the Pleistocene megafauna of Bahía, Brazil. Proc Natl Acad Sci USA 93: 6405-6409.

CHORNOGUBSKY L \& KRAMARZ AG. 2012. Nuevos hallazgos de Microbiotheriidae (Mammalia, Marsupialia) en la Formación Pinturas (Mioceno temprano, Argentina). Ameghiniana 49: 442-450.

COOKE S, ROSENBERGER AL \& TURVEY S. 2011. An extinct monkey from Haiti and the origins of Greater Antillean primates. Proc Natl Acad Sci USA 108: 2699-2704.

COHEN KM, FINNEY SC, GIBBARD PL \& FAN JX. 2013. The ICS international chronostratigraphic chart. Episodes 36 : 199-204.

FLEAGLE JG. 1990. New fossil platyrrhines from the Pinturas Formation, Southern Argentina. J Hum Evol 19: 61-85.

FLEAGLE JG \& TEJEDOR MF. 2002. Early platyrrhines of southern South America. In: Hartwig WC (Ed), The Primate Fossil Record. Cambridge University Press, Cambridge, p.161-174.

FLEAGLE JG, POWERS DW, CONROY GC \& WATTERS JP 1987. New fossil platyrrhines from Santa Cruz Province, Argentina. Folia Primatol 48: 65-77.

FLEAGLE JG, BOWN TM, SWISHER III CC \& BUCKLEY G. 1995. Age of the Pinturas and Santa Cruz Formations. Actas VI Congreso Argentino de Paleontología y Bioestratigrafía, Trelew, p. 129-135.

FLEAGLE JG, PERKINS ME, HEIZLER MT, NASH B, BOWN TM, TAUBER AA, DOZO MT \& TEJEDOR MF. 2012. Absolute and relative ages of fossil localities in the Santa Cruz and Pinturas Formations. In: Vizcaíno SF, Kay RF \& Bargo MS (Eds), Early Miocene Paleobiology in Patagonia: High-Latitude Paleocommunities of the Santa Cruz Formation. Cambridge University Press, Cambridge, p. 41-58.

FLYNN JJ, WYSS AR, CHARRIER R, SWISHER III CC. 1995. An Early Miocene anthropoid skull from the Chilean Andes. Nature 373: 603-607.

GOIN FJ, TEJEDOR MF \& ABELLO MA. 2010. Un nuevo microbiotérido (Mammalia, Marsupialia, Microbiotheria) de la Formación Pinturas (Mioceno temprano) de la provincia de Santa Cruz. Ameghiniana 47(1): 117-122.

GONZÁLEZ LR, TEJEDOR MF \& SCILLATO-YANÉ GJ. 2006. LOS Dasypodidae de La Formación Pinturas (Mioceno Inferior) Provincia de Santa Cruz. XXII Jornadas Argentinas de Paleontología de Vertebrados. 22 al 24 de Mayo, San Juan (San Juan), Argentina. Ameghiniana 43(4): 40R.
HALENAR LB \& ROSENBERGER AL. 2013. A closer look at the "Protopithecus" fossil assemblages: new genus and species from Bahia, Brazil. J Hum Evol 65(4): 374-390.

HARTWIG WC \& CARTELLE C. 1996. A complete skeleton of the giant South American primate Protopithecus. Nature 381: 307-311.

HERSHKOVITZ P. 1970. Notes on Tertiary platyrrhine monkeys and description of a new genus from the late Miocene of Colombia. Folia Primatol 12: 1-37.

HERSHKOVITZ P. 1974. A new genus of late Oligocene monkey (Cebidae, Platyrrhini) with notes on postorbital closure and platyrrhine evolution. Folia Primatol 21: 1-35. HOFFSTETTER R. 1969. Un primate de l'Oligocene inférieur sudamericain: Branisella boliviana gen. et sp. nov. Comptes Rendus de l'Académi des Sci, Paris, sér. D., 69: 434-437.

KAY RF \& COZZUOL MA. 2006. New platyrrhine monkeys from the Solimões Formation (late Miocene, Acre State, Brazil). J South Am Earth Sci 50: 673-686.

KAY RF, MADDEN RH, PLAVCAN JM, CIFELLI RL \& GUERRERO DIAZ J. 1987. Stirtonia victoriae, a new species of Miocene Colombian primate. J Hum Evol 16:173-196.

KAY RF, ROSS CF \& WILLIAMS BA. 1997. Anthropoid origins. Science 275: 797-804.

KAY RF, JOHNSON DJ \& MELDRUM DJ. 1998. A new pitheciin primate from the middle Miocene of Argentina. Am J Primatol 45: 317-336.

KAY RF, WILLIAMS BA \& ANAYA F. 2002. The adaptations of Branisella boliviana, the earliest South American monkey. In: Plavcan JM et al. (Eds), Reconstructing behavior in the primate fossil record. Klumer Academic/ Plenum Publisher, New York, p. 339-370.

KAY RF, FLEAGLE JG, MITCHELL TRT, COLBERT M, BOWN TM \& POWERS DW. 2008. The anatomy of Dolichocebus gaimanensis, a stem platyrrhine monkey from Argentina. J Hum Evol 54: 323-382.

KAY RF, HUNT KD, BEEKER CD, CONRAD GW, JOHNSON CC \& KELLER J. 2011. Preliminary notes on a newly discovered skull of the extinct monkey Antillothrix from Hispaniola and the origin of the Greater Antillean monkeys. J Hum Evol 60: 124-128.

KAY RF, VIZCAÍNO SF \& BARGO MS. 2012. A review of the paleoenvironment and paleoecology of the Miocene Santa Cruz Formation. In: Vizcaíno SF, Kay RF \& Bargo MS (Eds), Early Miocene Paleobiology in Patagonia: HighLatitude Paleocommunities of the Santa Cruz Formation. Cambridge University Press, Cambridge, UK, 331-364. 
KAY RF, GONZALES LA, SALENBIEN W, COOKE B, ANGEL L, RIGSBY C \& BAKER PA. 2019. Parvimico materdei gen. et sp. nov.: A new platyrrhine from the Early Miocene of the Amazon Basin, Peru. J Hum Evol 1: 134.

KRAGLIEVICH JL. 1951. Contribuciones al conocimiento de los primates fósiles de la Patagonia. I. Diagnosis previa de un nuevo primate fósil del Oligoceno superior (Colhuehuapiano) de Gaiman, Chubut. Revista del Museo Argentino de Ciencias Naturales 2: 57-82.

KRAMARZ AG \& BELLOSI ES. 2005. Hystricognath rodents from the Pinturas Formation, early - middle Miocene of Patagonia: biostratigraphic and paleoenvironmental implications. J South Am Earth Sci 18: 199-212.

KRAMARZ AG \& BOND M. 2005. Los Litopterna (Mammalia) de la Formación Pinturas, Mioceno Temprano-Medio de Patagonia. Ameghiniana 42(3): 611-625.

KRAUSE JM, RAIGEMBORN MS, BOWN TM \& TEJEDOR MF. 2016. Paleoclimate of the lower Pinturas Formation, middle Miocene, Santa Cruz province, Argentina. XII Congreso Latinoamericano de Sedimentología XV Reunión Argentina de Sedimentología, Santa Rosa, La Pampa, Argentina 103.

LUCHTERHAND K, KAY RF \& MADDEN RH. 1986. Mohanamico hershkovitzi, gen. et sp. nov., un primate du Miocène moyen d'Amérique du Sud. Comptes Rendus de l'Académie des Sci, Paris, sér. II. 303: 1753-1758.

LUND P 1840. Nouvelles recherches sur la faune fossile du Brésil. Ann Sci Naturelles, Paris, 13: 310-319.

MACPHEE RDE \& HOROVITZ I. 2004. New craniodental remains of the Quaternary Jamaican monkey Xenothrix mcgregori (Xenotrichini, Callicebinae, Pitheciidae), with a reconsideration of the Aotus hypothesis. Am Mus Novitates 3434: 1-51.

MACPHEE RD, ITURRALDE-VINENT MA \& GAFFNEY ES. 2003. Domo de Zaza, an Early Miocene Vertebrate Locality in South-Central Cuba, with Notes on the Tectonic Evolution of Puerto Rico and the Mona Passage 3394: 1-43.

MARIVAUX L, SALAS-GISMONDI R TEJADA J, BILLET G, LOUTERBACH M, VINK J \& ANTOINE PO. 2012. A platyrrhine talus from the early Miocene of Peru (Amazonian Madre de Dios SubAndean Zone). J Hum Evol 63 5: 696-703.

MARIVAUX L, ADNET S, ALTAMIRANO AJ, BOIVIN M, PUJOS F, RAMDARSHAN A, SALAS GISMONDI R, TEJADA LARA JV \& ANTOINE PO. 2016a. Neotropics provide insights into the emergence of New World monkeys: New dental evidence from the late Oligocene of Peruvian Amazonia. J Hum Evol 97: 159-175.
MARIVAUX L, ADNET S, ALTAMIRANO-SIERRA AJ, PUJOS F, RAMDARSHAN A, SALAS-GISMONDI R, TEJADA-LARA JV \& ANTOINE PO. 2016b. Dental remains of cebid platyrrhines from the earliest late Miocene of Western Amazonia, Peru: Macroevolutionary implications on the extant capuchin and marmoset lineages. Am J Phys Anthropol 161(3): 478-493.

MARIVAUX L, AGUIRRE DÍAZ W, BENITES PALOMINO A, BILLET G, BOIVIN M, PUJOS F, SALAS GISMONDI R, TEJADA LARA JV, VARAS MALCA R \& ANTOINE PO. 2020. New record of Neosaimiri (Cebidae, Platyrrhini) from the late Middle Miocene of Peruvian Amazonia. J Hum Evol 146: 102835.

NOVO NM \& FLEAGLE JG. 2015. New specimens of Platyrrhine primates from the early Miocene Pinturas Formation, Argentina. Ameghiniana 52(3): 367-372.

NOVO NM, TEJEDOR MF \& GONZÁLEZ RUIZ LR. 2018. Previously unknown fossil platyrrhines (Primates) of Patagonia from the Tournouër collection at the Muséum National d'Histoire Naturelle, Paris. Geodiversitas 40(4): 529-535

NOVO NM, TEJEDOR MF, PÉREZ ME \& KRAUSE M. 2017. NeW primate locality from the early Miocene of Patagonia, Argentina, Am J Phy Anthropol 164: 861-867.

PERKINS ME, FLEAGLE JG, HEIZLER MT, NASH B, BOWN TM, TAUBER AA \& DOZO MT. 2012. Tephrochronology of the miocene Santa Cruzand Pinturas formations, Argentina. In:Vizcaíno SF, Kay RF, Bargo MS (Eds), Early Miocene Paleobiology in Patagonia: High-Latitude Paleocommunities of the Santa Cruz Formation. Cambridge University Press, United Kingdom, p. 23-40.

PERRY JMG, KAY RF, VIZCAÍNO SF \& BARGO MS. 2010. Tooth Root Size, Chewing Muscle Leverage, and the Biology of Homunculus patagonicus (Primates) from the late early Miocene of Patagonia. Ameghiniana 47(3): 355-371.

PERRY JMG, KAY RF, VIZCAÍNO SF \& BARGO MS. 2014. Oldest known cranium of a juvenile New World monkey (Early Miocene, Patagonia, Argentina): Implications for the taxonomy and the molar eruption pattern of early platyrrhines. J Hum Evol 74: 67-81.

RIVERO M \& ARREDONDO O. 1991. Paralouatta varonai, a new Quaternary platyrrhine from Cuba. J Hum Evol 21: $1-11$.

ROSENBERGER AL. 1977. Xenothrix and Ceboid phylogeny. J of Hum Evol 6: 461-481.

ROSENBERGER AL, HARTWIG W \& WOLF RG. 1991a. SzalatavuS attricuspis, an early platyrrhine primate from Salla, Bolivia. Folia Primatol 56: 225-233.

ROSENBERgER AL, SETOGUCHI T \& HARTWIG WC. 1991b. Laventiana annectens, New Genus and Species Fossil 
Evidence for the Origins of Callitrichine. In: Rosenberger AL, Setoguchi T \& Hartwig WC (Eds), New World Monkeys 88(6): 2137-2140.

ROSENBERGER AL, COOKE SB, RÍMOLI R, NIX \& CARDOSA L. 2011. First skull of Antillothrix bernensis, an extinct relict monkey from the Dominican Republic. Proc Royal Soc B: Biol Sci 278: 67-74.

ROSENBERGER AL, HALENAR L, COOKE S, TEJEDOR MF, HARTWIG WC, NOVO NM \& MUÑOZ-SABA Y. 2015. Fossil alouattines and the origin of Alouatta: craniodental diversity and interrelationships. In: Kowalewski M, Garber P, CortésOrtíz L, Urbani B \& Youlatos D (Eds), Howler Monkeys: Examining the Evolution, Physiology, Behavior, Ecology, and Conservation of the Most Widely Distributed Neotropical Primate. Book Series Developments in Primatology: Progress and Prospects (Series editor: Russell H. Tuttle). Springer Press, p. 21-54.

RUSCONI C. 1933. Nuevos restos de monos fósiles del Terciario antiguo de la Patagonia. Anales de la Sociedad Científica Argentina 116: 286-289.

SEIFFERT ER, TEJEDOR MF, FLEAGLE JG, NOVO NM, CORNEJO FM, BOND M, DE VRIES D \& CAMPBELL KE. 2020. A parapithecid stem anthropoid of African origin in the Paleogene of South America. Science 368 (6487): 194-197.

SETOGUCHI T \& ROSENBERGER AL. 1985. Miocene marmosets: first evidence. Int J Primatol 6: 615-625.

STIRTON RA. 1951. Ceboid monkeys from the Miocene of Colombia. Univ Cal Publ Bull Dept Geol Sci 28(11): 315-356.

TAKAI M. 1994. New specimens of Neosaimiri fieldsi from La Venta, Colombia: a middle Miocene ancestor of the living squirrel monkeys. J Hum Evol 27: 329-360.

TAKAI M, ANAYA F, SHIGEHARA N \& SETOGUCHI T. 2000. NeW fossil materials of the earliest New World monkey, Branisella boliviana, and the problem of platyrrhine origins. Am J Phys Anthropol 111: 263-281.

TAKAI M, ANAYA F \& SUZUKI H. 2001. A New Platyrrhine from the Middle Miocene of La Venta, Colombia and the Phyletic Position of Callicebinae. Anthropol Sci 109(4): 289-307.

TAKAI M, NISHIMURA T, SHIGEHARA N \& SETOGUCHI T. 2009. Meaning of the canine sexual dimorphism in fossil owl monkey Aotus dindensis, from the middle Miocene of La Venta, Colombia. In: Comparative Dental Morphology. Koppe T, Meyer G \& Alt KW (Eds), Front Oral Biol Basel: Karger 13: 55-59.

TEJEDOR MF. 2000. Los Platyrrhini fósiles de la Patagonia (Primates, Anthropoidea). Sistemática, filogenia e inferencias paleoambientales. Tesis Doctoral inédita,
Facultad de Ciencias Naturales y Museo, Universidad Nacional de la Plata.

TEJEDOR MF. 2005a. New fossil platyrrhine from Argentina. Folia Primatologica 76(3): 146-150.

TEJEDOR MF. 2005b. New specimens of Soriacebus adrianae, with comments on pitheciin primates from the Miocene of Patagonia. Ameghiniana 42(1): 249-251.

TEJEDOR MF. 2002. Primate canines from the early Miocene Pinturas Formation, Southern Argentina. J Hum Evol 43: 127-141.

TEJEDOR MF \& ROSENBERGER AL. 2008. A neotype for Homunculus patagonicus Ameghino, 1891, and a new interpretation of the taxon. PaleoAnthropol 68-82.

TEJEDOR MF \& NOVO NM. 2018. Origen e historia evolutiva de los primates platirrinos: nuevas evidencias. In: Urbani B (Ed), Primatología en Latinoamérica 2.

TEJEDOR MF, TAUBER AA, ROSENBERGER AL, SWISHER III CC \& PALACIOS ME. 2006. New primate genus from the Miocene of Argentina. Proc Natl Acad Sci USA 103(14): 5437-5441.

TEJEDOR MF, ROSENBERGER AL \& CARTELLE C. 2008. Nueva especie de Alouatta (Primates, Atelinae) del Pleistoceno Tardío de Bahía, Brasil. Ameghiniana 45(1): 247-251.

TEJEDOR MF, NOVO NM, HOGG RT \& ROSENBERGER AL 2012. Dental macro- and micromorphology of a new pitheciid primate from the Miocene of Patagonia. $81^{\text {st }}$ Annual Meeting of the American Association of Physical Anthropologists (Portland), Abstracts. Am J Phys Anthropol 147 (S54): 284.

WILLIAMS EE \& KOOPMAN KF. 1952. West Indian Fossil Monkeys. Am Mus Novitates 1546: 1-16.

\section{How to cite}

NOVO NM, TEJEDOR MF, GONZÁLEZ-RUIZ LR, FLEAGLE JG, BRANDONI D \& KRAUSE M. 2021. Primate diversity in the early Miocene Pinturas Formation, southern Patagonia, Argentina. An Acad Bras Cienc 93: e20201218. DOI 10.1590/0001-3765202120201218.

Manuscript received on July 30, 2020;

accepted for publication on September 7, 2020

\section{NELSON MARTÍN NOVO ${ }^{1}$}

https://orcid.org/0000-0001-9732-0673

MARCELO FABIÁN TEJEDOR ${ }^{1,2,3}$

https://orcid.org/0000-0003-3465-673X

LAUREANO RAÚL GONZÁLEZ-RUIZ ${ }^{4}$

https://orcid.org/0000-0001-8875-5202 


\section{JOHN G. FLEAGLE 5}

https://orcid.org/0000-0003-3162-808X

\section{DIEGO BRANDONI}

https://orcid.org/0000-0001-5934-7699

\section{MARCELO KRAUSE ${ }^{7,8}$}

https://orcid.org/0000-0002-2166-2455

${ }^{1}$ Instituto Patagónico de Geología y Paleontología (CCT

CONICET - CENPAT), 9120 Puerto Madryn, Chubut, Argentina

${ }^{2}$ Universidad Nacional de la Patagonia "San Juan

Bosco", Facultad de Ciencias Naturales, Sede

Trelew, 9100, Trelew, Chubut, Argentina

${ }^{3}$ Global Biodiversity Centre, Research Associate,

Box 461, SE 405 30, Göteborg, Sweden

${ }^{4}$ Universidad Nacional de La Patagonia San Juan Bosco (UNPSJB), Laboratorio de Investigaciones en Evolución y Biodiversidad (LIEB-FCNyCS sede Esquel, UNPSJB) y Centro de Investigaciones Esquel de Montaña y Estepa Patagónica (CIEMEP), CONICET, Roca 780, 9200, Esquel, Chubut, Argentina

${ }^{5}$ Stony Brook University, Department of Anatomical Sciences, School of Medicine, Stony Brook, NY 11794-8081, U.S.A.

${ }^{6}$ Centro de Investigación Científica y de Transferencia Tecnológica a la Producción (CICYTTP, CONICET-Prov. ERUADER), Laboratorio de Paleontología de Vertebrados, España 149, E3105BWA Diamante, Argentina

${ }^{7}$ CONICET, Museo Paleontológico Egidio Feruglio (CONICET), Avenida Fontana 140, 9100 Trelew, Chubut Argentina.

${ }^{8}$ Universidad Nacional de Río Negro, Av. Roca 1242, 8332 General Roca, Río Negro, Argentina

Correspondence to: Nelson Martín Novo

E-mail:nelsonovo@gmail.com

\section{Author contributions}

All authors listed have made an important, precise, and intellectual contribution to the work.

\section{(cc) BY}

